\title{
Diversity, Concentration and Dynamics of Culturable Fungal Bioaerosols at Doha, Qatar
}

\author{
Raghdaa K. Fayad, Roda F. Al-Thani, Fatima A. Al-Naemi and Mohammed H. Abu-Dieyeh *(D)
}

check for updates

Citation: Fayad, R.K.; Al-Thani, R.F.; Al-Naemi, F.A.; Abu-Dieyeh, M.H. Diversity, Concentration and Dynamics of Culturable Fungal Bioaerosols at Doha, Qatar. Int. J. Environ. Res. Public Health 2021, 18, 182. https://doi.org/10.3390/ ijerph18010182

Received: 6 April 2020

Accepted: 12 May 2020

Published: 29 December 2020

Publisher's Note: MDPI stays neutral with regard to jurisdictional claims in published maps and institutional affiliations.

Copyright: () 2020 by the authors. Licensee MDPI, Basel, Switzerland. This article is an open access article distributed under the terms and conditions of the Creative Commons Attribution (CC BY) license (https: / / creativecommons.org/ licenses/by/4.0/).
Department of Biological and Environmental Sciences, College of Arts and Sciences, Qatar University, Doha 2713, Qatar; 200551272@student.qu.edu.qa (R.K.F.); ralthani@qu.edu.qa (R.F.A.-T.);

Fatima.Alnaemi@ccq.edu.qa (F.A.A.-N.)

* Correspondence: dandelion@qu.edu.qa

\begin{abstract}
This research was conducted to investigate the dynamics of airborne fungi using viable culture collection and in respect to different abiotic variables, including seasonal and intra-diurnal variations. A gravimetric method was used to sample airborne fungal deposition on potato dextrose agar plates on alternate days, for a year between April 2015 to March 2016. From 176 settle plate exposures, a total of 1197 mould and 283 yeast colony-forming units (CFU), 21 genera and 62 species were retrieved. The highest fungal spore count was recorded in February 2016, whereas the lowest count occurred in August 2015. The main constituents of the fungal airspora were attributed to Cladosporium (60.2\%), Aspergillus (10.4\%), Fusarium (9.4\%), Alternaria (8.5\%), and Ganoderma spp. (2.3\%). Temperature was negatively correlated with total colony count $(r=-0.231, p \leq 0.05)$ or species richness $(r=-0.267, p \leq 0.001)$, while wind speed was positively correlated with total colony count $(r=0.484, p \leq 0.001)$ or species richness $(r=0.257, p \leq-0.001)$. The highest dispersal of fungal spores was obtained at 18:00, whereas the lowest fungal spores release was recorded at 00:00 (midnight). There were no significant differences in species composition and richness of the airborne fungal population between two study sites, the Industrial area and Qatar University Campus. The count of Alternaria spp. and Fusarium spp. were significantly higher at the Industrial area site, which corresponds to a higher $\mathrm{CO}_{2}$ level than the Qatar University site. This study lays the foundation for future work to assess the implications of such aeromycological data on public health.
\end{abstract}

Keywords: aerobiology; aeromycology; seasonal variations; intra-diurnal variations; $\mathrm{CO}_{2}$ concentration; meteorological parameters

\section{Introduction}

Aeromycology is the scientific study of airborne fungal spores, including their release, concentrations, composition and the parameters affecting their dynamics in the atmosphere [1]. As a branch of aerobiology, aeromycological studies help aerobiologists, plant pathologists and allergist by providing baseline information on the predominance of fungal populations and their dynamics due to abiotic interactions [1].

Airborne fungi cause negative effects on humans', animals' and plants' health [1,2]. The allergen production by fungi is influenced by their life cycle following atmospheric release during spore germination [3]. Fungal spores are small in size and exist in respectable quantity in the atmosphere. They are implicated in respiratory allergies, and symptoms include asthma, allergic rhinitis and bronchitis [4]. It has been demonstrated that environmental factors, such as meteorological and seasonal climate conditions, vegetation, air pollution and human activities influences airborne fungal spore formation and transport [5-7]. Several studies were conducted with the aim of detecting the dynamics of aeromycota in associations with the biotic and abiotic factors of their surrounding environment in many parts of the world, some of these include India [8], Australia [9], Chile [10], Poland [11] and China [12]. However, to the best of our knowledge, only few aeromycological studies were conducted in the Middle East compared to other continents, 
these comprise Israel [13], Jordan [14,15], Egypt [16], Turkey [17], Iran [18], Saudi Arabia $[19,20]$ and Kuwait $[21,22]$. Although the impact of meteorological factors on air quality is considerable and well established, studies concerning the relationship between fungal counts and air pollutants are still few [23]. The increasing level of atmospheric carbon dioxide $\left(\mathrm{CO}_{2}\right)$ could significantly affect airborne fungal growth and subsequently influence their dispersal rate [24]. As a result of increasing atmospheric $\mathrm{CO}_{2}$, which often elevates the carbon-to-nitrogen ratio and plant biomass, the sporulation rate of Alternaria alternata was substantially increased [25].

In Qatar, only one study was carried out on the dynamics of airspora of Doha for a whole year (1997-1998) [26]. The author concluded that the mycoflora in the air of Doha exhibited a seasonal and diurnal variation in which Cladosporium, Alternaria and Ulocladium were the most abundant genera in the atmosphere of Doha [26]. Qatar is a peninsula located in the Arabian Gulf region. Plant coverage is infrequent and scattered due to the shortage in water supplies, mainly varied between herbaceous plants, shrubs and a limited number of tree species [27]. Doha is the capital of Qatar and the most popular city, and the increasing anthropogenic activities arising from road and mass housing constructions within the last 15 years could influence species dynamics.

This study aims to: (1) provide baseline knowledge about density, diversity and dynamics of airborne fungal spores in the atmosphere of Doha using settle plate exposures, (2) investigate variations in seasonal and intra-diurnal patterns and to correlate variations with meteorological factors and (3) correlate the variations in species composition and abundance of airborne fungi with atmospheric $\mathrm{CO}_{2}$ concentration.

\section{Materials and Methods}

\subsection{Study Area}

Qatar is a peninsula occupying an area of more than $11,000 \mathrm{~km}^{2}$ and a coastline of $900 \mathrm{~km}$ in length. It lies in the Arabian Peninsula at $25^{\circ} 35^{\prime} 48^{\prime \prime} \mathrm{N}$ and $51^{\circ} 18^{\prime} 39^{\prime \prime} \mathrm{E}$ and is connected to Saudi Arabia in the south, bordered by a very shallow, semi-enclosed sea characterized by hyper-salinity (39-41) practical salinity unit (psu) for surface water) [28]. Geographically, it is a flat, rocky and arid desert and in the south, sand dunes are the predominant features. As a subtropical desert, Qatar is hot and has dry weather, the annual rainfall is about $81 \mathrm{~mm}$, and the average maximum air temperature is $31^{\circ} \mathrm{C}$, although the maximum temperature could exceed $47^{\circ} \mathrm{C}$ [29]. Doha is the capital of the state, located on the eastern Qatari coastal line at $25^{\circ} 17^{\prime} 12^{\prime \prime} \mathrm{N}, 51^{\circ} 32^{\prime} 0^{\prime \prime} \mathrm{E}$. It is the most urbanized and populous city in the state, the population in the country until February 2015 was 2,116,400 [30].

The present study was carried out at Qatar University, which is located on the northern side of the capital Doha at $25^{\circ} 37^{\prime} 47^{\prime \prime} \mathrm{N}, 51^{\circ} 49^{\prime} 03^{\prime \prime} \mathrm{E}$. The main habitat and associated vegetation in the northern part of Qatar is characterized by 'rodat' areas, in which compact soils are common. This type of soils usually supports more moisture and organic matter than other desert parts. Vegetation type ranges from trees and shrubs to grasses and herbs, and common species include Acacia spp., Prosopis juliflora, Ziziphus nummularia and Lycium shawii [31]. Because this area accommodates larger rodats, they have been utilized as farms for growing crops [28]. Within the campus of Qatar University, naturally occurring plants are widespread; additionally, many species associated with man-made and man-influenced sites, such as gardens, green houses and roadsides, are very common.

\subsection{Seasonal Variations in Airborne Fungal Populations in Doha City}

A gravimetric method (settle plate exposure) using a Petri dish was carried out directly on the roof of the building of Qatar University (about $12 \mathrm{~m}$ above ground level, including the height of the metal mount). One Petri dish ( $9 \mathrm{~cm}$ diameter) containing Potato Dextrose Agar (PDA) (Hi-Media Laboratories, Mumbai, India) amended with chloramphenicol $(1 \mathrm{~g} / \mathrm{L})$, was exposed for $15 \mathrm{~min}$, which resulted in more accurate colony counts, at 15:00 on each of 3 days per week (alternate days), from the beginning of April 2015 to the end 
of March 2016. Total exposures of 176 plates were collected during the year of study. After sampling, the plates were incubated at $25^{\circ} \mathrm{C}$ for $3-5$ days.

Daily meteorological data from Qatar University weather station were supplied by the Weather Record Department, Doha, Qatar. The meteorological data considered are minimum and maximum daily temperature, minimum and maximum relative humidity, daily rainfall, wind direction and wind speed.

\subsection{Intra-Diurnal Variations in Airborne Fungal Populations in Doha City}

A period of two months, February and March (2016), was chosen to investigate intra-diurnal variations in fungal populations of Doha, mainly because this period was preliminarily explored as a period of greatest diversity in species composition in Doha's atmosphere. One Petri dish (9 $\mathrm{cm}$ diameter) containing PDA was exposed to air for $15 \mathrm{~min}$ at 6-h intervals (at 06:00, 12:00, 18:00 and 00.00) during the period of 1 February to 31 March 2016. After sampling, the plates were incubated at $25^{\circ} \mathrm{C}$ for $3-5$ days. During the whole period, a data logger (OMEGA Engineering INC., Swedesboro, NJ, USA) was installed at the site of collection to monitor temperature and relative humidity at intervals of one hour.

\subsection{Effect of $\mathrm{CO}_{2}$ Concentration on Species Composition and Abundance of Fungal Spore Populations}

Two locations at Doha city were chosen to investigate the impact of $\mathrm{CO}_{2}$ level on species composition and abundance of fungal spore populations. Qatar University is one of these locations, which is relatively far from industrial areas $(\sim 25 \mathrm{~km})$, and the other is close to the central industrial area (Industrial Area). Industrial area is a district of Doha, Qatar, with coordinates $25^{\circ} 10^{\prime} 3^{\prime \prime} \mathrm{N}$ and $51^{\circ} 26^{\prime} 22^{\prime \prime} \mathrm{E}$.

During the period of 1 February to 31 March 2016, Petri dishes $(9 \mathrm{~cm}$ diameter) containing PDA were exposed to the air for $15 \mathrm{~min}$ on alternate days. In respect to the two locations and during sampling, the plates were opened at the same time and for the same exposure period ( $15 \mathrm{~min})$. After sampling, the plates were brought to the lab using an icebox and then incubated at $25^{\circ} \mathrm{C}$ for $3-5$ days. The grown fungal colonies for each species were counted and the total colony counts were recorded. A portable $\mathrm{CO}_{2}$ data logger (CO2METER Inc., Ormond Beach, $\mathrm{FL}$, USA) was used to record $\mathrm{CO}_{2}$ concentration every minute during the collection period. The average of the 15 readings per sampling was recorded.

\subsection{Identification of Airborne Fungal Spores}

The fungal grown colonies for each species were counted and recorded. For classification, fungal colonies were isolated and purified on Potato Dextrose Agar (PDA) and other selective agars like Malt Extract Agar (MEA) (HiMedia Laboratories Pvt.Ltd, Maharashtra, India) and Czapek's / Rose-Bengal agar (HiMedia Laboratories Pvt.Ltd, Maharashtra, India), then, they were incubated for $3-5$ days at $25^{\circ} \mathrm{C}$. Identification was based on the macro- and micro-scopic features following the keys and description given by many authors [32-39].

\subsection{Statistical and Data Analysis}

Statistical analyses were performed to correlate the mean daily fungal spore counts and species composition with the daily data of the meteorological parameter of the same day and for the whole year using Pearson's correlation coefficient. Similar correlation analyses were performed to investigate the effect of $\mathrm{CO}_{2}$ on species composition and abundance. To compare the $\mathrm{CO}_{2}$ concentration in the two study sites and as normality failed, a Mann-Whitney test on rank was applied based on 22 sampling exposures from each site. Analysis of variance (ANOVA) was performed to study the significant effect of intra-diurnal periods on deposition densities and species richness. The Shapiro-Wilk test was used to test the normality of data and Tukey's test was used to separate the means at $p \leq 0.05$. Temperature and relative humidity data from the data logger were averaged for each sampling time (e.g., between 18:00 and 24:00) and Pearson's correlation coefficient was performed to study the correlation between colony count of each sampling exposure 
with the average temperature or relative humidity. The Jaccard similarity coefficient was applied to compare the similarities in species composition (including species identified at the specific level and other taxa) among the four diurnal periods, as follows: Jaccard similarity coefficient $=(\mathrm{c} /(\mathrm{a}+\mathrm{b})-\mathrm{c}) \times 100, \mathrm{c}=$ number of common species between any two time periods ( $\mathrm{a}$ and $\mathrm{b}$ ). A T-test at significance level $p=0.05$ was accomplished to study the significance in daily colony counts between the two study sites according to differences in $\mathrm{CO}_{2}$ concentrations.

\section{Results}

\subsection{Seasonal Variations in Airborne Fungal Populations in Doha City}

From the air of Doha, the total colony count number retrieved from 176 exposure samplings during the year of study (1 April 2015 to 31 March 2016) was 283 yeast and 1197 mould colony-forming units (CFU). The mould colonies belong to 21 genera and 62 species (Table 1).

The maximum count of airborne fungal spores was recorded in February 2016, whereas the minimum occurred in September 2015. The main constituents of the airborne fungi population in the atmosphere of Doha were attributed to the genera: Cladosporium (60.2\%), Aspergillus (10.4\%) Fusarium (9.4\%), Alternaria (8.5\%), Ganoderma spp. (2.3\%) and Penicillium (2.0\%) (Figure 1).

Cladosporium was the most common fungal taxa in the air of Doha, comprising around two thirds of the total colony counts representing five species. C. cladosporioides was the most dominant species, with $70.5 \%$ of the total of the genus Cladosporium, followed by C. macrocarpum with $9.2 \%$ and C. sphaerosprmum with $6.4 \%$. Cladosporium had double peaks of occurrence (April and February) and the lowest occurrence in July (Table 1; Figure 2).

Aspergillus sp. was the second predominant fungal genera represented by ten species (Table 1). Aspergillus achieved the highest deposition density in August 2015 and the lowest in January 2016 (Figure 2) A. flavus abundance was $46.5 \%$ of the total among the genus Aspergillus, then A. sydowii with 25.2\% (Table 1; Figure 1). Fusarium was ranked as the third among the most common airborne fungi in Doha. Most recovered colonies of Fusarium spp. were identified at the genus level, however F. oxysporum and F. chlamydosporum were the most abundant and frequently recorded (Table 1). Alternaria represented the fourth most prevalent fungal taxa, with seven identified species. The spore count of $A$. alternata put up with more than half of the whole genus (61.4\%), followed by A. chlamydospora $(12.8 \%)$, then A. infectoria (11.9\%) (Table 1; Figure 1). Both Alternaria and Fusarium reached their maximum deposition densities in July 2015, the spore count of Alternaria spp. declined in June 2015, while Fusarium colony counts diminished in January 2016 (Figure 2). Interestingly, Ganoderma spp. was ranked fifth among the most predominant fungi in the atmosphere of Doha, with $2.4 \%$ abundance, even though they exclusively appeared in February and March 2016 of the whole year (Table 1; Figure 1). 


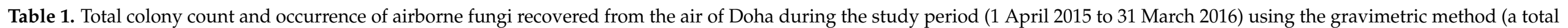
of 176 exposure samplings). Bold fonts refer to the genus and its related data.

\begin{tabular}{|c|c|c|c|c|}
\hline Fungal Taxa & No. of Colonies & (a) Colony Count $(\%)$ & (b) Monthly Occurrence & Month of Presence \\
\hline Acremonium sp. & 3 & 0.25 & 1 & December \\
\hline Acrophialophora & 4 & 0.33 & 1 & June \\
\hline Acrophialophora fusispora (S.B. Saksena) Samson & 4 & 0.33 & 1 & June \\
\hline Alternaria & 102 & 8.52 & 11 & Yearly, except June \\
\hline Alternaria alternata (FR.) Keissler & 62 & 5.18 & 11 & Yearly, except June \\
\hline Alternaria brassicicola (Schwein.) Wiltshire & 3 & 0.25 & 1 & February \\
\hline Alternaria chlamydospora Mouchacca & 13 & 1.09 & 3 & December, January, February \\
\hline Alternaria phragmospora V. Emden & 2 & 0.17 & 2 & February, April \\
\hline Alternaria porri (Ellis) Cif. & 4 & 0.33 & 1 & December \\
\hline Alternaria tenuissima (Kunze) Wilt. & 6 & 0.50 & 2 & May, July \\
\hline Aspergillus & 124 & 10.36 & 12 & Yearly \\
\hline Aspergillus flavus species complex & 59 & 4.93 & 11 & Yearly, except January \\
\hline Aspergillus fumigatus species complex & 2 & 0.17 & 1 & November \\
\hline Aspergillus alutaceus species complex & 5 & 0.42 & 2 & December, March \\
\hline Aspergillus terreus species complex & 3 & 0.25 & 2 & April, May \\
\hline Aspergillus versicolor species complex & 35 & 2.92 & 5 & \\
\hline Aspirgillus ustus species complex & 5 & 0.42 & 2 & July, February \\
\hline Blastomyces sp. & 2 & 0.17 & 1 & December \\
\hline Cladosporium & 721 & 60.23 & 12 & Yearly \\
\hline Cladosporium cladosporioides species complex & 509 & 42.52 & 12 & Yearly \\
\hline Cladosporium herbarum (Pers.) Link & 4 & 0.33 & 3 & October, December, February \\
\hline Cladosporium macrocarpum Preuss & 66 & 5.51 & 9 & Yearly, except June, August and September \\
\hline Cladosporium oxysporum Berk. \& M.A. Curtis & 13 & 1.09 & 4 & February, March, April, May \\
\hline Cladosporium sp. & 80 & 6.68 & 1 & April \\
\hline Cladosporium sphaerosprmum Penzig & 46 & 3.84 & 11 & Yearly, except November \\
\hline Cladosporium tenuissimum Cooke & 3 & 0.25 & 3 & November, February, March \\
\hline Cochliobolus & 18 & 1.50 & 8 & April, June, July, August, September, October, December \\
\hline Cochliobolus australiencsis (Tsuda \& Ueyama) Alcorn & 6 & 0.50 & 4 & June, July, September \\
\hline Cochliobolus hawaiinsis Alcorn (anamorph) & 3 & 0.25 & 1 & August \\
\hline Cochliobolus lunatus Nelson \& Haasis (anamorph) & 4 & 0.33 & 1 & April \\
\hline Cochliobolus spicifer Nelson (anamorph) & 5 & 0.42 & 2 & October, December \\
\hline
\end{tabular}


Table 1. Cont.

\begin{tabular}{|c|c|c|c|c|}
\hline Fungal Taxa & No. of Colonies & (a) Colony Count $(\%)$ & (b) Monthly Occurrence & Month of Presence \\
\hline Epicoccum & 2 & 0.17 & 2 & May, June \\
\hline Epicoccum nigrum & 2 & 0.17 & 2 & May, June \\
\hline Fusarium & 113 & 9.44 & 12 & Yearly \\
\hline Fusarium sp. & 76 & 6.35 & 8 & January, February, March, April, May, October, November \\
\hline Fusarium chlamydosporum Wollenweber \& Reinking & 10 & 0.84 & 5 & November, December, January, February, March \\
\hline Fusarium dimerum Penzig & 8 & 0.67 & 5 & April, May, December, February, March \\
\hline Fusarium moniliforme (A. Braun) Wollenweber & 3 & 0.25 & 1 & October \\
\hline Fusarium oxysporum species complex & 16 & 1.34 & 6 & October, November, December, February, March, April \\
\hline Geotrichum & 2 & 0.17 & 1 & June \\
\hline Geotrichum candidum Link & 2 & 0.17 & 1 & June \\
\hline Mucor sp. & 2 & 0.17 & 1 & March \\
\hline Myrothecium & 2 & 0.17 & 1 & December \\
\hline Myrothecium verrucaria (Alb. \& Schwein) Ditmar & 2 & 0.17 & 1 & December \\
\hline Penicillium & 24 & 2.01 & 4 & January, February, March, May, June \\
\hline Phoma & 4 & 0.33 & 1 & March \\
\hline Phoma glomerata (Corda) Wollenw. & 4 & 0.33 & 1 & March \\
\hline Pleospora & 7 & 0.58 & 3 & April, May, December \\
\hline Rhizopus stolonifer (Ehrenb.) Lind & 3 & 0.25 & 2 & March \\
\hline Stachybotrys & 6 & 0.50 & 2 & December, March \\
\hline Stachybotrys chartarum (Ehrenb.) Hughes & 3 & 0.25 & 1 & December \\
\hline Stachybotrys elegans (Pidopl.) W. Gams & 3 & 0.25 & 1 & March \\
\hline Thanatephorus & 2 & 0.17 & 1 & January \\
\hline Thanatephorus cucumeris (Frank) Donk & 2 & 0.17 & 1 & January \\
\hline Ulocladium & 15 & 1.25 & 4 & \\
\hline Ulocladium botrytis Preuss & 9 & 0.75 & 2 & March, July \\
\hline Ulocladium chartarum (Preuss) Simmons & 6 & 0.50 & 2 & March, May \\
\hline UNKNOWN & 9 & 0.75 & 3 & January, March, May \\
\hline MOULDS & 1197 & 80.88 & 12 & Entire year \\
\hline YEASTS & 283 & 19.12 & 12 & Entire year \\
\hline Total No. of Fungal Colonies & \multicolumn{4}{|c|}{1480} \\
\hline
\end{tabular}

${ }^{(a)}$ Calculated as a percentage of the total count of mould colonies (1197) recovered from the entire study. ${ }^{(b)}$ Number of months of occurrence out of 12 months. 


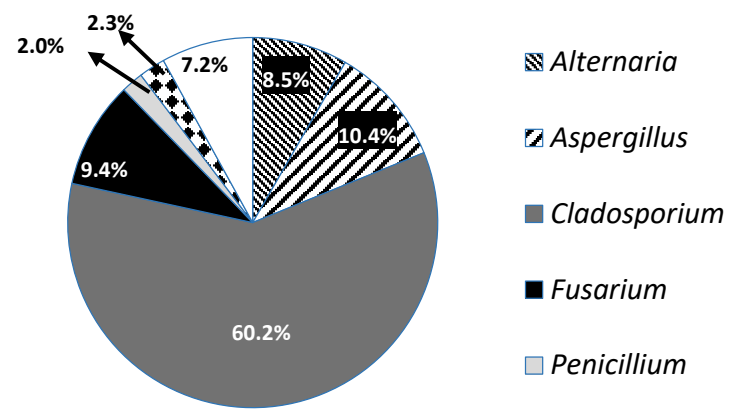

Figure 1. The composition of fungal constituents (\%) in the atmosphere of Doha City during 1 April 2015 to 31 March 2016, using the gravimetric method (a total of 176 exposure samplings).

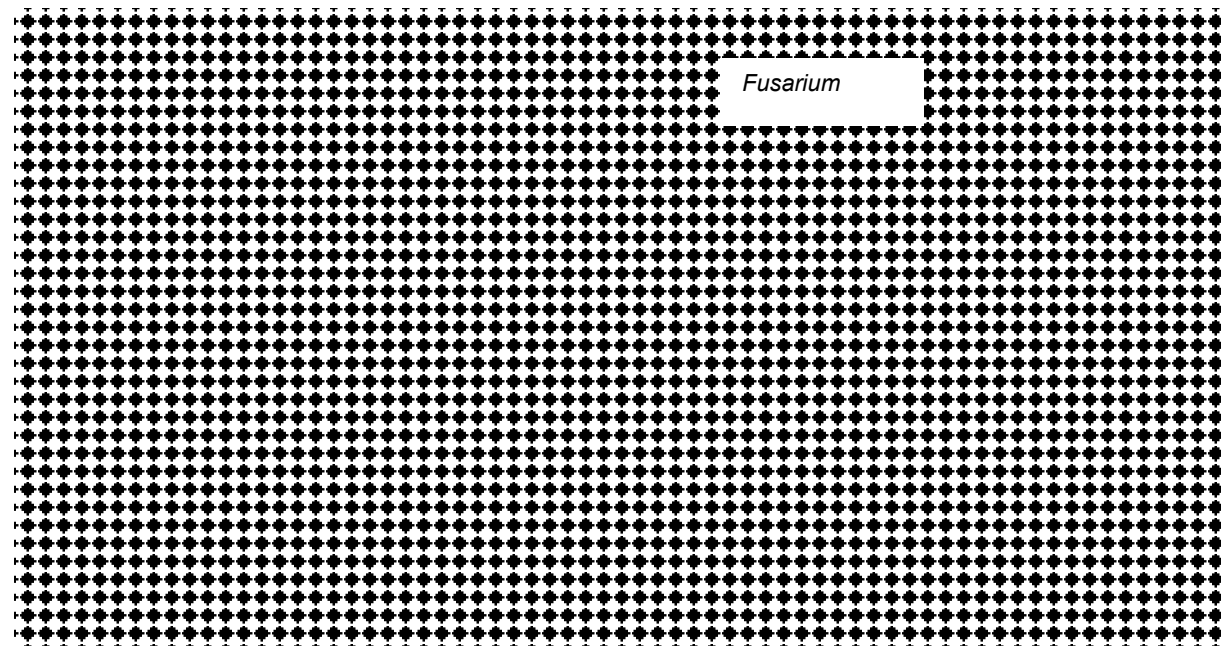

Figure 2. Seasonal variation of the four most common fungal genera in the atmosphere of Doha during the year of study (1 April 2015 to 31 March 2016) using the gravimetric method (a total of 15 exposure samplings per month).

\subsection{Weather Interactions with Airborne Fungi of Doha}

According to the correlation analyses between weather parameters and the incidence of the main fungal taxa, total daily or monthly colony count and species diversity are presented in Table 2. Both daily and monthly counts of either of Cladosporium or Alternaria spores showed significant negative correlations $(p \leq 0.05)$ with daily maximum, minimum and mean temperatures. While the correlations of Cladosporium colony count with both daily or monthly relative humidity and rainfall were not significant, the monthly rainfall data showed a highly significant correlation $(p \leq 0.01)$ with Alternaria colony counts. A high significant $(p \leq 0.01$ ) positive correlation occurred between daily counts of Cladosporium and Alternaria and wind speed (Table 2). On the contrary, Aspergillus deposition density showed non-significant correlations with any of the studied weather parameters (Table 2). Fusarium daily colony counts had the only significant correlation $(p \leq 0.01)$ with the daily wind speed data (Table 2). On the other hand, total daily colony counts of all encountered fungi showed significant negative correlations $(p \leq 0.05)$ with all daily temperature parameters. A high significant positive correlation $(p \leq 0.01)$ was also observed between the total daily or monthly colony count and daily or monthly wind velocity (Table 2), and a nonsignificant correlation with either of daily mean relative humidity or rainfall. However, no significant correlation occurred between total colony counts and either relative humidity or rainfall. Daily temperature parameters showed negative correlations with fungal species diversity of Doha's atmosphere, while daily wind speed data exhibited a significant positive correlation $(p \leq 0.01)$ with species diversity (Table 2$)$. There was no significant correlation between air-borne fungi and wind direction (Table 2). 


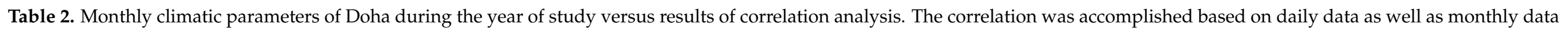
and using Pearson correlation coefficient.

\begin{tabular}{|c|c|c|c|c|c|c|c|}
\hline \multirow{2}{*}{ Month } & \multicolumn{3}{|c|}{ Temperature $\left({ }^{\circ} \mathrm{C}\right)$} & \multirow{2}{*}{$\begin{array}{c}\text { Mean Relative Humidity } \\
(\%)\end{array}$} & \multirow{2}{*}{ Total Rainfall (mm) } & \multirow{2}{*}{ Mean Wind Speed (m/s) } & \multirow{2}{*}{$\begin{array}{l}\text { Mean Wind Direction } \\
\text { (Degree) }\end{array}$} \\
\hline & Maximum & Minimum & Mean & & & & \\
\hline April 2015 & 35.5 & 23.6 & 29.0 & 27.6 & 0.0 & 4.3 & $255.7=\mathrm{WSW}^{\mathrm{a}}$ \\
\hline May & 41.0 & 28.7 & 34.4 & 26.0 & 0.0 & 4.2 & $243.3=$ WSW \\
\hline June & 42.2 & 29.8 & 35.8 & 31.7 & 0.0 & 4.3 & $297.1=\mathrm{WNW}$ \\
\hline July & 40.7 & 32.2 & 36.2 & 45.0 & 0.0 & 3.7 & $230.0=\mathrm{SW}$ \\
\hline August & 41.8 & 32.1 & 36.1 & 58.9 & 0.0 & 2.7 & $214.3=S W$ \\
\hline September & 39.9 & 30.0 & 34.3 & 55.8 & 0.0 & 2.5 & $265.0=W$ \\
\hline October & 36.7 & 27.2 & 31.4 & 59.9 & 0.0 & 2.7 & $308.3=\mathrm{NW}$ \\
\hline November & 29.4 & 21.3 & 25.0 & 66.7 & 0.0 & 2.4 & $317.8=\mathrm{NW}$ \\
\hline December & 23.7 & 15.9 & 19.5 & 69.7 & 0.2 & 3.0 & $292.5=\mathrm{WNW}$ \\
\hline January 2016 & 22.9 & 14.3 & 18.1 & 66.3 & 0.1 & 3.1 & $256.3=$ WSW \\
\hline February & 24.0 & 15.5 & 19.4 & 59.5 & 0.0 & 2.9 & $233.1=\mathrm{SW}$ \\
\hline March & 27.6 & 19.0 & 23.1 & 58.3 & 1.3 & 3.1 & $185.7=\mathrm{S}$ \\
\hline \multicolumn{8}{|c|}{ Correlation Coefficients/Daily Weather Data versus Daily Data of Number of Fungal Colonies } \\
\hline Cladosporium & $-0.231 *$ & $-0.228 *$ & $-0.237 *$ & -0.0828 & -0.0328 & $0.427 * *$ & 0.175 \\
\hline Alternaria & -0.243 * & $-0.193 *$ & $-0.222 *$ & 0.0125 & -0.0243 & $0.323 * *$ & -0.111 \\
\hline Aspergillus & 0.0135 & 0.0347 & 0.0209 & 0.0459 & -0.0737 & 0.0779 & 0.0909 \\
\hline Fusarium & 0.025 & 0.0906 & 0.0673 & -0.0697 & -0.0276 & $0.329 * *$ & 0.084 \\
\hline Total daily colony count & $-0.23 *$ & $-0.215^{*}$ & $-0.231 *$ & -0.102 & -0.0519 & $0.484^{* *}$ & 0.155 \\
\hline Total daily number of species & $-0.26 * *$ & $-0.26 * *$ & $-0.267^{* *}$ & -0.0249 & -0.0917 & $0.257^{* *}$ & 0.143 \\
\hline \multicolumn{8}{|c|}{ Correlation Coefficients/Monthly Weather Data versus Monthly Data of Total Number of Colonies } \\
\hline Cladosporium & $-0.625 *$ & $-0.703 *$ & $-0.666^{*}$ & 0.14 & 0.108 & 0.129 & 0.267 \\
\hline Alternaria & $-0.203^{* *}$ & $-0.154 *$ & $-0.18^{* *}$ & 0.36 & $0.562 * *$ & -0.253 & 0.569 \\
\hline Aspergillus & -0.724 & -0.696 & -0.712 & 0.468 & 0.77 & -0.141 & -0.179 \\
\hline Fusarium & 0.0846 & 0.0595 & 0.0821 & -0.217 & 0.125 & 0.37 & -0.348 \\
\hline Total monthly colony count & -0.684 & 0.189 & 0.189 & 0.189 & 0.307 & 0.115 & 0.181 \\
\hline Total monthly number of species & -0.642 & -0.681 & -0.66 & 0.173 & 0.468 & 0.022 & -0.241 \\
\hline
\end{tabular}

${ }^{(* *)}$ Highly significant correlation at $p \leq 0.01,\left({ }^{*}\right)$ Significant correlation at $p \leq 0.05 .{ }^{\text {a }} \mathrm{W}=$ West, $\mathrm{E}=$ East, $\mathrm{N}=\mathrm{North}, \mathrm{S}=$ South 


\subsection{Diurnal Variations of Fungal Spore Populations in the Atmosphere of Doha}

During the two months of study (1 February to 31 March 2016), the mean daily maximum temperature ranged from 24.6 to $27.3^{\circ} \mathrm{C}$, the mean daily minimum temperature ranged between 15.0 and $18.7{ }^{\circ} \mathrm{C}$. The daily relative humidity varied from $39 \%$ to $84 \%$. Significant differences $(p \leq 0.05)$ in colony count and species diversity were found among the four studied periods. The highest colony count and species diversity were recovered at 18:00, while the lowest were reported at 00:00 (midnight). No significant differences in colony counts as well as species diversity between 12:00 and 18:00 were observed (Table 3). The highest similarity coefficient in species composition was obtained between 00:00 and 06:00, while the lowest was detected between 18:00 and 00:00 (Table 4).

Table 3. Diurnal variation of species richness and abundance (mean total colony count) of airborne fungi in the atmosphere of Doha, Qatar, with respect to variations in temperature and relative humidity. A total of 72 exposure samplings were obtained during the period 1 February to 31 March 2016.

\begin{tabular}{ccccc}
\hline Sampling Time & Mean Temp ${ }^{\circ} \mathbf{C}$ & Mean RH \% & $\begin{array}{c}\text { Total Colony } \\
\text { Count }\end{array}$ & $\begin{array}{c}\text { Total Number of } \\
\text { Fungal Species * }\end{array}$ \\
\hline $06: 00$ & 18.2 & 70.3 & $143^{\mathrm{bc}}$ & $23^{\mathrm{ab}}$ \\
$12: 00$ & 24.5 & 43 & $195^{\mathrm{ab}}$ & $23^{\mathrm{ab}}$ \\
$18: 00$ & 23.1 & 52.5 & $214^{\mathrm{a}}$ & $30^{\mathrm{a}}$ \\
$00: 00$ & 19.5 & 63.5 & $79^{\mathrm{c}}$ & $15^{\mathrm{b}}$ \\
\hline
\end{tabular}

* Within each column, means followed by common letters are not significantly different at $p=0.05$ according to Tukey's test.

Table 4. Similarity * table among different diurnal times with respect to fungal species encountered from 72 exposure samplings in the atmosphere of Doha, Qatar, during the period 1 February to 31 March 2016.

\begin{tabular}{ccccc}
\hline Time & $\mathbf{0 0 : 0 0}$ & $\mathbf{0 6 : 0 0}$ & $\mathbf{1 2 : 0 0}$ & $\mathbf{1 8 : 0 0}$ \\
\hline $00: 00$ & $100 \%$ & $65 \%$ & $58 \%$ & $41 \%$ \\
$06: 00$ & $65 \%$ & $100 \%$ & $48 \%$ & $56 \%$ \\
$12: 00$ & $58 \%$ & $48 \%$ & $100 \%$ & $39 \%$ \\
$18: 00$ & $41 \%$ & $56 \%$ & $39 \%$ & $100 \%$ \\
\hline
\end{tabular}

* Jaccard similarity coefficient $=(c /(a+b)-c) \times 100 . c=$ number of common species between any two time periods ( $a$ and $b)$.

The mean daily colony count was negatively correlated $(p \leq 0.05)$ with mean daily relative humidity and positively correlated $(p \leq 0.05)$ with mean daily temperature (Figure 3 ). However, no significant correlations were found between species diversity and any of the weather parameters. Interestingly, the mean daily counts of the genera Alternaria and Ganoderma have shown significant positive correlations $(p \leq 0.05)$ with the mean daily temperature. The most abundant fungal taxa retrieved throughout the two months at the four periods were Cladosporium cladosporioides, Alternaria spp., Fusarium spp., Ganoderma, Ulocladium botrytis and Aspergillus (Figure 4). 


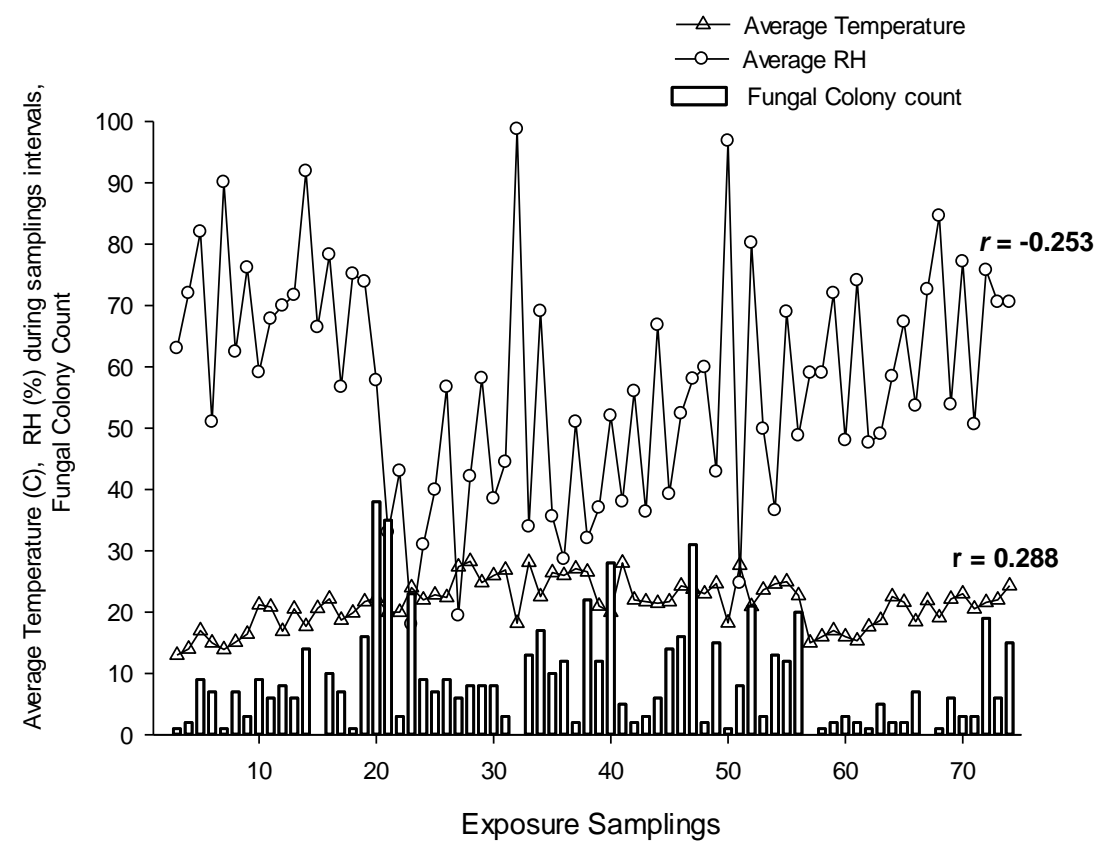

Figure 3. Variations in fungal colony counts in each exposure sampling with respect to changes in average temperature and relative humidity $(\mathrm{RH})$ during the $6 \mathrm{~h}$ intervals. Correlation coefficient values $(r)$ are significantly different between mean daily counts and mean daily temperature and mean daily relative humidity at $p \leq 0.05$, according to Pearson's correlation coefficient.

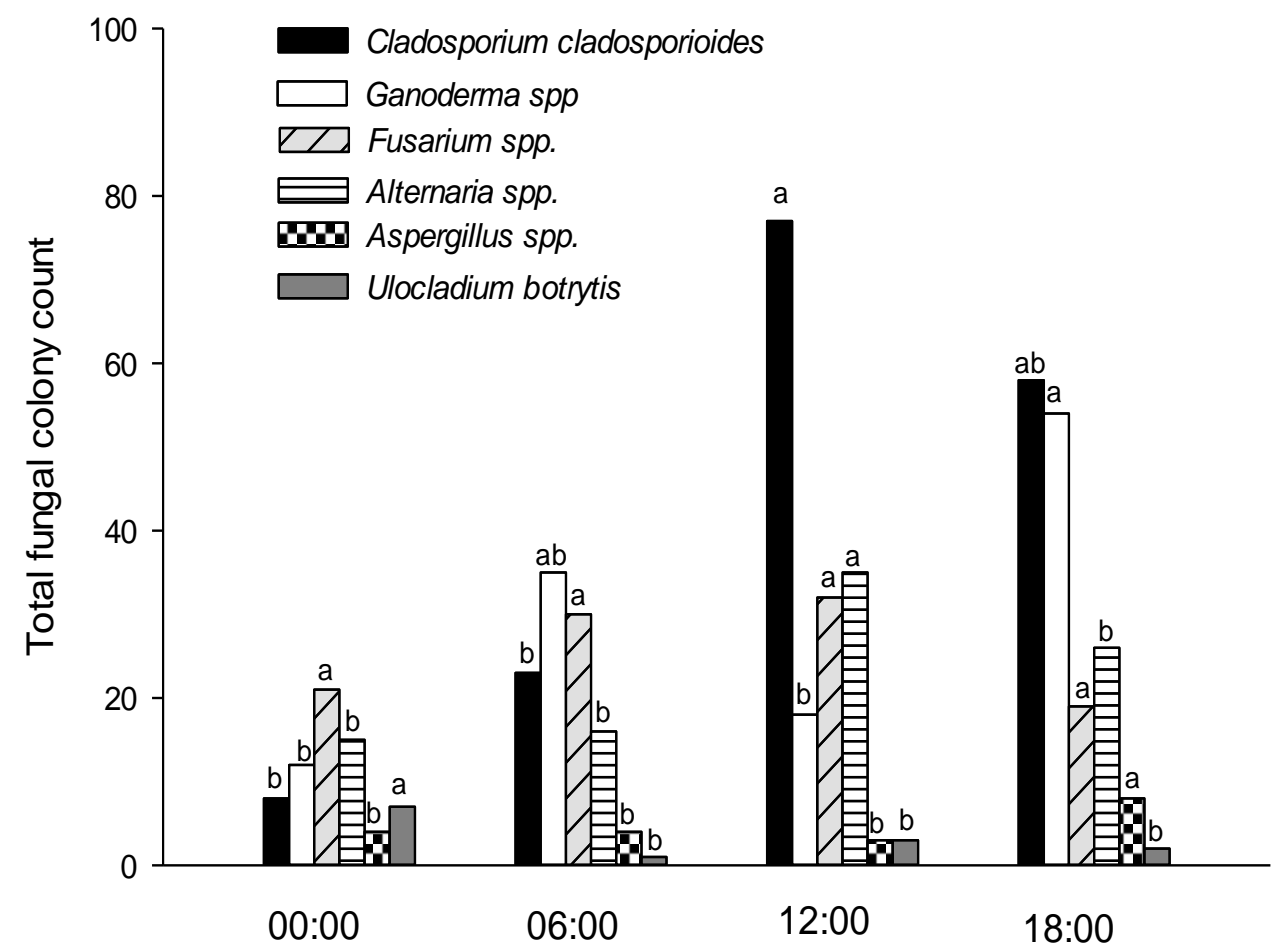

Figure 4. Diurnal variations in total fungal colony counts of the most common species in the atmosphere of Doha during the period 1 February to 31 March 2016. A total of 72 exposure samplings. Within each fungal taxa, values with common letters are not significantly different at $p \leq 0.05$, according to Tukey's test. Significant correlations were reported between mean daily temperature and the mean daily counts of Alternaria spp. $(r=0.316)$ and mean daily counts of Ganoderma spp. $(r=0.237)$ at $p \leq 0.05$, according to Pearson's correlation coefficient. 
Cladosporium cladosporioides represented a mid-day (12:00) peak and had a minor peak at 18:00, while its deposition density significantly declined $(p \leq 0.05)$ at midnight (00:00) and in the early morning hours (06:00). Ganoderma spp. significantly peaked ( $p \leq 0.05)$ at 18:00 and showed similar abundance among the other three periods. Alternaria had a significant mid-day (12:00) peak pattern, while the colony count significantly declined in the other three periods. No significant differences in Fusarium colony count were reported among the four studied periods, while Aspergillus had a major peak pattern at 18:00 and Ulocladium botrytis at midnight (00:00) (Figure 4).

\subsection{The Impact of Atmospheric $\mathrm{CO}_{2}$ Concentration on the Dynamics of Airborne Fungi}

The two-month study (1 February to 31 March 2016) revealed that 12 fungal genera and 31 fungal species were collected from the Qatar University Campus site, while 16 fungi genera and 35 species were collected from the Industrial Area site. No significant differences were observed in the total number of colonies and fungal species between the two study sites, although daily concentration of $\mathrm{CO}_{2}$ was higher (according to average, median and range values of $\mathrm{CO}_{2}$ ) at the Industrial area site (average $=513 \pm 167 \mathrm{ppm}$ ) than Qatar University Campus (average $=335 \pm 92$ ). Applying the non-parametric Mann-Whitney test on rank indicated a significant difference $(p<0.001, n=22)$ in $\mathrm{CO}_{2}$ concentrations between the two sites. The common and most abundant fungal taxa recorded in the two study sites were Cladosporium, Ganoderma, Fusarium and Alternaria. Corresponding to $\mathrm{CO}_{2}$ concentrations, the daily colony count of Cladosporium was significantly higher at Qatar University Campus than the Industrial area $(p \leq 0.05)$ (Figure 5). Contrary to Cladosporium, the deposition density of Fusarium and Alternaria were significantly higher $(p \leq 0.05)$ at the Industrial area site (Figure 5).

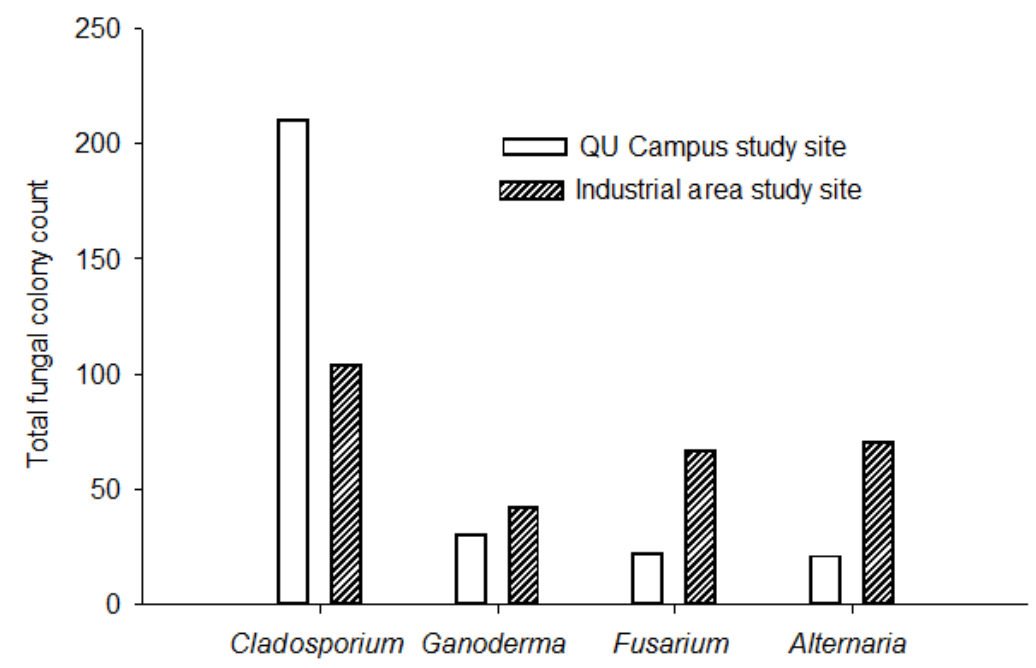

Figure 5. Fungal taxa that showed significant abundance differences between the two study sites (according to the t-test of daily colony count at $p=0.05$ ) during the period of 1 February to 31 March 2016, with a total of 22 exposure samplings.

The main constituents of fungal genera and their abundance rate in the atmosphere of the two study sites were widely variable between the two sites (Figure 6). Cladosporium was prominently higher in relative abundance $(67 \%)$ at the University campus, constituting about two thirds of fungal composition. Other fungi like Ganoderma, Fusarium and Alternaria were also part of the main composition, with relative abundances of $11 \%, 7 \%$ and 6\%, respectively. Other taxa at the University Campus had 10\% abundance (Figure 6), while Cladosporium remain the main constituent of fungal taxa at the Industrial Area site, however, relative abundance (29\%) was very low compared to the University site $(67 \%)$ (Figure 6). Interestingly, Ganoderma showed similar relative abundances (11\%) in the two 
sites (Figure 6). The fungal genera, Alternaria and Fusarium, were considered to be the main constituents with relative abundances of $19 \%$ and $17 \%$, respectively; however, other taxa are still represented by $23 \%$ (Figure 6).

\section{Industrial area study site}

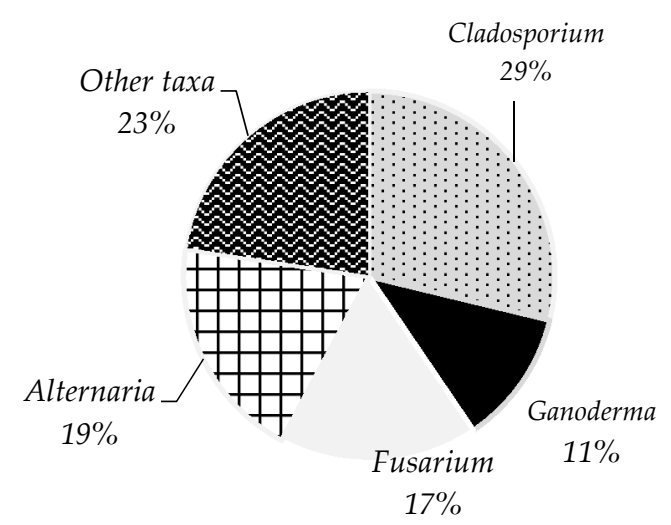

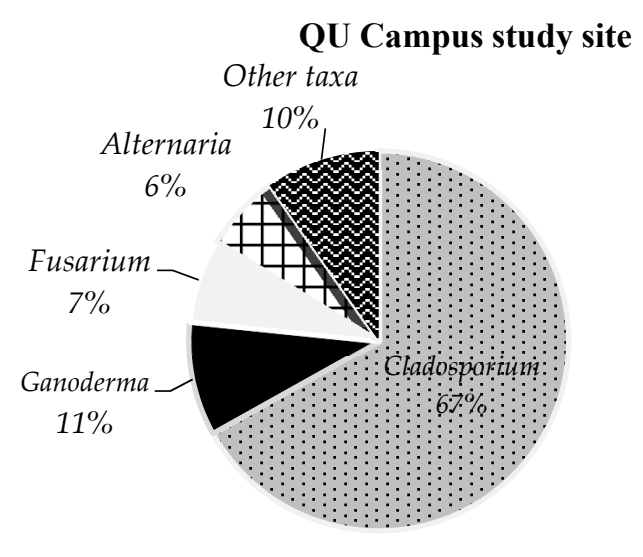

Figure 6. Pie graph to show the main constituents of fungal genera and their relative abundances in the atmosphere of the two study sites during the period of 1 February to 31 March 2016, with a total of 22 exposure samplings.

\section{Discussion}

\subsection{Seasonal Dynamics of Air-Borne Fungi of Doha}

During the year of study, a total of 1197 colony counts and 21 genera assigned to 62 species were retrieved. Cladosporium, Aspergillus Fusarium, Alternaria, Ganoderma spp. and Penicillium were the main components of the air mycoflora of the Doha area. Several studies demonstrated the presence of the above-mentioned fungal taxa as part of the main aeromycota composition in different Middle Eastern countries [15,19]. According to another study conducted in Doha, Qatar [26], the major airborne fungal genera obtained were Cladosporium, Alternaria and Ulocladium. Although the method of collection used in Al-Subai's study is similar to the one used in the present study, there exist some differences in the experimental setup and design. For instance, the collection height used by Al-Subai was $1.5 \mathrm{~m}$, but in the present study, a height of $12 \mathrm{~m}$ above the ground level was used, which is considered more realistic in such aerobiological studies [10]. Another major difference is the culture media used, $1 \%$ glucose-Czapek's agar $+0.05 \%$ yeast extract culture medium versus Potato Dextrose Agar (PDA), in this study. Both, the height level of collection and culture media used are considered variables that affect the sampled species composition and abundance of air mycoflora [40-44]. These, in addition to the increased anthropogenic activities over the last 17 years that occurred in Qatar, may explain the differences in the results obtained.

Our study showed that Cladosporium was the most common fungal genus and commonly occurred throughout the study periods with double peaks, one in April and another in February. Many authors presented Cladosporium as the main air mycoflora in different countries [14,26,45]. Many factors might support the abundance of Cladosporium throughout the year. It has been demonstrated that the structural features of Cladosporium conidia, such as a chlamydospore-like structure, make them more resistant to solar radiation and physicochemical agents $[26,46]$; however, other authors explained this phenomenon by referring to the small size, thin exine and smooth wall of the Cladosporium spores, which helps in the dissemination of conidia $[47,48]$.

Aspergillus sp. was the second predominant fungal genera, with ten species recorded. Aspergillus presented a seasonal pattern: the highest deposition density was in August and the lowest in January. Aspergillus sp. was the predominant taxa in many countries' outdoor environments, like Kuwait [22] and Saudi Arabia [19,49]. 
The abundance of Aspergillus sp. in the atmosphere of Doha and other Gulf regions is consistent with the findings of Christensen and Tuthill, who found that the tropical/subtropical habitats accommodated higher numbers of Aspergillus species in comparison to temperate regions [50]. Accordingly, they concluded that Aspergillus genus is highly abundant in the tropics/subtropics, especially in the saline and cultivated soils.

Additionally, Fusarium was ranked as the third airborne fungi. Fusarium is a cosmopolitan fungus, which is a well-known plant/animal pathogen [51]. Fusariun hardly germinates in low water activity environments [52]. The dispersion of Fusarium macrocnidia was found to follow a rain or irrigation event [53]. Indeed, it was reported that Fusarium was abundant in the atmosphere of the Zarqa area, Jordan, and this abundance correlated with the continuous drip irrigation of olive plantations in the study site, and the existence of many farms [15]. This may explain the abundance of Fusarium in the atmosphere of Doha, since Qatar University campus receives extensive and frequent irrigations to accommodate the need of the vegetation cover (turfgrass areas and others) and the high evaporation rate. However, rainfall might interact with density of Fusarium, but it is difficult to achieve any significant correlation trends since the rainfall in Qatar is very low and limited to a few days of the year.

Alternaria represented the fourth most prevalent fungal taxa in the air of Doha, with seven species identified. Alternaria represented a seasonal trend, with high colony count in May and July, while the colony count declined a little and maintained all over the year with almost minor fluctuations. Similar to Cladosporium spores, the conidia of Alternaria are of dry spore's type and dark colour, which tolerate the solar radiation and survive the whole year [26]. Other studies showed that the highest spore deposition of Alternaria spp. was reported in July and August, following wet weather [54,55].

Ganoderma spp. was one of the major constituents of air mycoflora of Doha (2.4\%), but it was exclusively retrieved in February and March. In the present study, Ganoderma spp. has been identified for the first time in the atmosphere of Doha. A similar study in Jizan, Saudi Arabia, also found a considerable concentration of Ganoderma basidiospores within the airspora [56]. According to the authors, airborne Ganoderma spp. was not frequently detected in many countries with similar ecological features in the Gulf region. Ganoderma was first suggested to be associated with respiratory allergy in 1952 by Gregory and Hirst [57]. In Jizan, Saudi Arabia, the concentration of Ganoderma basidiospores was significantly correlated with the high incidence of asthma in Jizan [56]. The seasonal pattern of Ganoderma widely varies worldwide. For example, in Jizan region of Saudi Arabia, the seasonal trend of Ganoderma is from October to March, with a peak in December and January when the temperature is moderate and the humidity is relatively high [56]. In Poland, it was found that August is the month of the highest spore incidence, when the weather is warm and humid [11]. In the USA, the spores of Ganoderma were reported on more than $95 \%$ of the days, of June through October, and reaching a maximum concentration in late August until mid-October, with a positive correlation with temperature and precipitation [58]. In Delhi, India, Ganoderma had a seasonal pattern from July to September [59]. The presence of Ganoderma basidiospores is determined by the abundance of vegetation coverage [60], and the maximum spore concentration was reported to occur during the rainy months [61]. From the above studies, the incidence of Ganoderma basidiospores seems to be more correlated with warm and high moisture or rainfall. Together, these studies corroborate our findings as recorded in February (10\%) and March (90\%) respectively (Table 2), when the temperature is moderate and the rainfall incidence is the highest in Doha, Qatar.

\subsection{Fungal Species Fluctuation versus Climatic Factors}

According to our results, February was the month of greatest colony count and fungal taxa recorded (Data not shown) in the atmosphere of Doha, and this could be linked to the relatively moderate temperature and high rainfall (Table 2). August and September were the months of lowest fungal abundance and diversity (Data not shown), these months are characterized by relatively high temperature and humidity (Table 2), which may interact 
to stop the dissemination of fungal spores from their sources (soil and plants) and/or destroy the spores, especially with the accompanying increase in sun radiation during these months.

Equally, an important, significant $(p \leq 0.01)$ positive correlation was obtained between the total daily fungal counts and fungal taxa recorded, which might indicate that similar interactions of weather conditions may determine the dynamics and fluctuation of both parameters. Both daily and monthly counts of either Cladosporium or Alternaria spores showed significant negative correlations $(p \leq 0.05)$ with daily maximum, minimum and mean temperatures. While the correlations of Cladosporium colony count with daily or monthly relative humidity and rainfall were not significant, the monthly rainfall data showed high significant correlation $(p \leq 0.01)$ with Alternaria colony counts. A high significant $(p \leq 0.01)$ positive correlation was also observed between daily counts of Cladosporium or Alternaria and daily wind speed data. Contrary to our results, in Poland, Grinn-Gofron and Strzelczak found that the concentration of air spores of Cladosporium and Alternaria were significantly and positively correlated to temperature, but negatively to relative humidity, however the authors could not clearly rank which weather parameter is more important for the viability of those fungal spores in the air [62]. Similarly, in Spain, Sabariego et al., in 2012, concluded that the mean daily count of Alternaria was significantly and positively correlated with temperature but negatively correlated to relative humidity, rainfall and wind speed [63]. In Turkey, both Alternaria and Cladosporium were significantly and positively correlated with temperature and humidity [64]. Our results showed similar trends with other studies that have been conducted in countries with a similar environment to Qatar [18,65-68]. Hasnain et al., in 2012, demonstrated that the occurrence of Alternaria spores is negatively correlated to temperature [65] and Hameed et al., in 2007, mentioned a negative correlation with relative humidity [66]. Studies have found that the concentration of Cladosporium spores increased significantly as the temperature decreased, which is in support of our findings [18]. The cumulative rainfall was positively correlated with the level of Alternaria incidence [54] and dispersal of Alternaria spores was higher in August following a period of wet weather [54]. In general, raindrops accelerate the release of dry spores like Alternaria spores. Combined together, these studies are in agreement with our results, suggesting the significant positive correlation between monthly data of Alternaria and rainfall.

Interestingly, the meteorological parameters could not influence the spore incidence of Aspergillus in the atmosphere of Doha. The nature of Aspergillus spores is dry and relatively small, which makes them easily and passively released by even minor wind speed or vibration [7]. Nevertheless, it appears that the inconsistency of the meteorological impacts on the dynamic of these airborne fungal spores may be the result of different climatic conditions in many countries. Our findings agreed with Oliveira et al., who found that Aspergillus had no correlation with any of the meteorological parameters [67]. However, contradicting our results, Aspergillus level was found to be positively and significantly correlated to temperature, but a negative correlation was observed when compared to relative humidity [40]. In a similar study, Aspergillus was said to be positively and significantly correlated to temperature, but negatively to relative humidity [68].

In the present study, the only significant correlation observed in Fusarium was to wind speed. Fernando et al., in 2000, noted that similar environmental conditions are favourable to some Fusarium species in release of their spores, and although rain could influence sporulation rate in Fusarium, it was, however, difficult to address the impact of other factors, such as soil surface temperature and wind velocity [53]. Fusariun germination is known to develop well in the presence of high moisture, and, as mentioned earlier, the abundance of Fusarium in the study site was attributed to extensive and frequent irrigation activities, aimed at accommodating the need for vegetation cover in addition to high evaporation rate [52].

Total daily colony count of all encountered fungi had negative correlations $(p \leq 0.05)$ with mean daily temperature. A highly significant positive correlation $(p \leq 0.01)$ was 
obtained between the total daily or monthly colony count and daily or monthly wind speed, and a negative but insignificant $(p \leq 0.05)$ correlation to the daily mean relative humidity and rainfall. However, no significant correlations were reported between total colony count and either relative humidity or rainfall. In agreement with our results, it has been found that the several fungal spore counts are negatively correlated with temperature, though a positive and insignificant correlation was detected with relative humidity [65]. Similarly, Nourian et al., detected a negative correlation between temperature and colony count but positive to relative humidity [18]. Other studies are, however, conflicting with our findings, indicating that concentration of airborne fungal spores was positively and significantly correlated with temperature [68].

Based on our statistical correlation analysis between weather data and fungal airspora, the temperature might have the greatest influence on the dynamics of airborne fungal spores, a fact that has been highlighted by many authors, see References [11,69]. Interestingly, the majority of retrieved fungal airspora are mesophilic (optimal temperature for growth $20-40^{\circ} \mathrm{C}$ ). Our results showed that relative humidity had no significant impact on the airborne fungi of Doha, which might be attributed to the adaptation of germination, growth and propagation of airborne fungi to relative humidity [18]. Another reason could be that the high temperature plus the sun radiation (not studied in the present study) may be more limiting factors than the humidity in certain months of the year, particularly from July to September. Wind speed was found to significantly exaggerate the number of fungal spores in the atmosphere, which correspond to our findings on all fungal taxa $[17,26,63,64]$. However, the impact of wind speed was related to the daily data, which means that the impact of wind velocity on the fungal airspora is temporal and, in part, on a daily basis, rather than accumulative effects. On the other hand, wind can act as a spore dispersal and diluting factor at high wind, and hence could significantly reduce spore concentrations [41]. According to Lin and Li, at a wind speed of less than $5 \mathrm{~m} / \mathrm{s}$, fungal spores concentration decreases, but increases at wind velocity higher than $5 \mathrm{~m} / \mathrm{s}$ [7]. The change in wind direction had no effect on fungal abundance or diversity. In 1980, McDonald and O'Driscoll found a remarkable impact of wind direction on the count of airborne fungi [70]. On the other hand, and coinciding with our findings, Al-Subai, could not detect any regular correlation between wind direction and the concentration of fungal spores, which might be related to the fact that Doha is a coastal city surrounded by the Arabian Gulf [26]. One of the limitations of this study is the alternate days of sampling, which had interruptions of fungal sampling data, and this might have an effect on the correlation analysis of non-consistent climatic parameters like wind speed and rainfall.

\subsection{Diurnal Variation of Fungal Spore Populations in the Atmosphere of Doha}

In the present study, the atmospheric deposition densities of fungal spores under the influence of intra-diurnal fluctuations were studied during the study period of 1 February to 31 March 2016. Several aeromycological studies have investigated the diurnal periodicity of airborne fungal spores $[15,16,26,71]$. Our findings revealed an intra-diurnal periodicity pattern of fungal spore deposition densities, suggesting significant differences in the total colony counts and fungal diversity at varying time periods. Both parameters, total colony count and species fungal diversity, peaked significantly in the atmosphere of Doha at 18:00 and declined significantly at 00:00. A negative correlation between colony count and relative humidity was observed, while a positive correlation with temperature was noted. During February and March, the daily temperatures in Doha are less fluctuated and moderate $\left(20-25^{\circ} \mathrm{C}\right)$, which suggests less dryness owing to high temperature and low humidity, which are necessary for spores' release into the atmosphere. Interestingly, a deposition density gradient of fungal spore was observed, which occurred in upward flux (started from 00:00) coordinating positively with recorded temperature and negatively with relative humidity. Previous studies revealed that the highest concentrations were recorded around $12 \mathrm{~h}$, concomitant with high temperature and decreased relative humidity [26,62,71]. On the other hand, Fengxiang et al. found that the viability of airborne fungi was higher 
at night than daytime, due to the darkness and high relative humidity, which increase the concentration of fungal spores [72]. However, the period of study is important in determining the diurnal periodicity of fungal spores [14]. Our study was conducted between February and March, which corresponds to the spring period in Qatar, and yet, the diurnal range of minimum humidity could not negatively affect fungal spore release or dissemination, which may allow temperature to be the effective variable in the diurnal cycle of fungal spore dissemination. The highest similarity coefficient was obtained between 00:00 (midnight) and 06:00 (early morning), while the lowest similarity coefficient was detected between 18:00 (afternoon) and 12:00 (noon). The most abundant fungal taxa were Cladosporium cladosporioides, Alternaria spp., Fusarium spp., Ganoderma, Ulocladium botrytis and Aspergillus. Cladosporium and Alternaria were found in higher deposition densities at mid-day. These two fungal taxa are of clinical importance due to their allergenic properties [73]. Elsewhere, different studies found that the maximum concentrations of Cladosporium and Alternaria also occur at mid-day [74].

Consistent with our findings, Cladosporium and Alternaria were found to have a positive correlation with temperature but were negatively correlated with relative humidity $[75,76]$. For Cladosporium, spores are dry air, thus, mid-day weather conditions, when the temperature is relatively high and relative humidity is low, present the optimal dispersal condition. For Alternaria, Recio et al. reported correlation coefficients in terms of maximum, minimum and mean temperature, and accordingly, they suggested that the concentration of Alternaria spore is a function of temperature [75]. It was demonstrated that the maximum release of Ganoderma spores occurred when the humidity increased and temperature diminished [76]. Similarly, Calderon et al. concluded that the release of basidiospores are negatively correlated to temperature and declines at higher temperatures of more than $27^{\circ} \mathrm{C}$ [77]. This is in agreement with our findings: Ganoderma was only detected in February and March with a peak at 18:00, when the average daily temperature was $23.1^{\circ} \mathrm{C}$ and the mean humidity was $52.5 \%$. Even though many authors highlighted temperature as more detrimental in the diurnal fungal cycle, we believe that a minimum degree of humidity is still needed for release of each fungal species. Mean rainfall during the study period was the highest throughout the year, and as basidiomycetes spores are wet, their dispersal could be directly affected by precipitation. Sufficient moisture, either during rain periods or when humidity is high, may be required for the spore production of Ganoderma [71,74]. By the splash and "tap-and-puff" mechanism, raindrops hit the leaves and cause the attached spores to be released from their colonies into the air [74]. From this study, the sporulation of Ganoderma is more associated to increased moisture than humidity.

Aspergillus had a major peak pattern at 18:00. There is no significant diurnal periodicity of Aspergillus/Penicillium due to the nature of their spores, as they are dry, relatively small and thus, they can be released passively by minor wind speed [7]. Hameed et al. observed a double peaks pattern of Aspergillus at 10:00 and at 20:00 [16]. The highest concentration of Aspergillus/Penicillium occurred at 00:00 [74]. In the current study, Ulocladium botrytis peaked at midnight (00:00). Indeed, Al-Suwaine et al. also found that the concentration of Ulocladium is negatively correlated to temperature [78].

\subsection{The Impact of Atmospheric Status ( $\mathrm{CO}_{2}$ Concentration) on the Dynamics of Airborne Fungi}

The concentrations of $\mathrm{CO}_{2}$ and other air pollutants increase with increased anthropogenic activities $[79,80]$. There were no significant differences in the composition and diversity of the airborne fungal population between the two study sites, though daily concentration of $\mathrm{CO}_{2}$ was significantly higher $(p \leq 0.001, n=22)$ at the Industrial area site than at Qatar University Campus. In agreement with our results, in Taiwan, Chung et al. [79], and from the USA, Klamer et al., demonstrated that the fungal abundance and their species richness were not significantly influenced by elevated $\mathrm{CO}_{2}$ levels [81].

Although the main constituents of the airspora in the two study sites were attributed to similar fungal taxa, Cladosporium, Ganoderma, Fusarium and Alternaria, their deposition densities and distribution rate in the atmosphere are significantly different. Cladosporium 
showed higher and significant deposition density at the Qatar University site in comparison to Fusarium and Alternaria, which were highly abundant in the Industrial area site; however, Ganoderma had a similar relative abundance rate. This might be explained by the fact that elevated concentration of atmospheric $\mathrm{CO}_{2}$ raises the sporulation rate in some fungal genera [82], and might decline others, via changing fungal metabolism, and could subsequently inhibit their growth pattern, spore production and other reproduction processes [82]. Rather than the atmospheric $\mathrm{CO}_{2}$, other air pollutants, such as ozone $\left(\mathrm{O}_{3}\right)$, nitrogen dioxide $\left(\mathrm{NO}_{2}\right)$, sulphur dioxide $\left(\mathrm{SO}_{2}\right)$ and particulate matter $\left(\mathrm{PM}_{10}\right)$, might influence the availability and biological activities of airborne fungal taxa $[80,83]$. Indeed, the colony counts of Alternaria spp. and Fusarium spp. were significantly higher at the Industrial area site, which corresponds to a high $\mathrm{CO}_{2}$ level. Further agreement to our findings were the results of a study by Klironomos et al., suggesting that spore production levels of Fusarium spp. and Alternaria spp. were stimulated under elevated $\mathrm{CO}_{2}$ concentration levels [24]. Additionally, Wolf et al., in 2010, demonstrated that sporulation in Alternaria alternata increased at elevated $\mathrm{CO}_{2}$ concentration [25]. Indeed, increased $\mathrm{CO}_{2}$ concentration provides plants with a higher carbon/nitrogen ratio; in this way, pathogenic plant fungi accelerate their growth and sporulation rate [84]. Our results were based on 22 sampling exposures from each of the two study sites, which might not be enough to explicitly see the effects of $\mathrm{CO}_{2}$ and industrialization on dynamics of airspora, though a full year of monitoring is suggested for future research.

\subsection{Respiratory Diseases and Airborne Fungal Spores}

In the present study, Cladosporium, Aspergillus, Fusarium, Alternaria, Ganoderma spp. and Penicillium represented the major fungal airspora in the atmosphere of Doha, Qatar. Those fungi are frequently reported to have an association with allergy [40,65]. In the Middle East, and particularly in the Gulf region, only a few studies have attempted to assess the prevalence of allergic rhinitis, conjunctivitis, bronchial asthma and allergic bronchopulmonary mycoses developed from the frequent exposure to allergenic spores. In Qatar, Taj-Aldeen et al. investigated the allergic fungal rhinosinusitis (AFS) cases caused by Aspergillus flavus, where they found a huge quantity of allergic fungal mucin and dark crusts fully colonizing the sinuses, which required a course of systemic and topical corticosteroids [85]. In another Qatari study, the size of fungal infections at the public level have been estimated [86]. The data analysis revealed that 1486 people were affected by severe asthma with fungal sensitization, 1126 patients were diagnosed with allergic bronchopulmonary and 176 individuals complained of chronic pulmonary aspergillosis [86]. In Saudi Arabia, Hasnain et al. found relations between the high prevalence of asthma in children and the highest concentration of Ganoderma spp., Cladosporium, Alternaria and Aspergillus were believed to significantly contribute to causing allergic rhinitis and allergic asthma [56].

In the present study, the deposition density of A. alternata contributed to more than half of the total Alternaria spp. A. alternata is considered as one of the most significant aeroallergens [87]. Species of A. fumigatus, A. niger, A. flavus and A.oryzae were frequently correlated with the respiratory allergic cases, and particularly $A$. flavus due to its large spores, use to deposit in the upper respiratory tract and commonly cause fungal sinusitis [88]. Cladosporium herbarum is an important and main cause of inhalant fungal allergens, among other Cladosporium species [73]. In the present study, C. herbarum showed a minor deposition compared with other Cladosporium species.

\section{Conclusions}

In conclusion, our study demonstrated a seasonal pattern of airborne fungi in the atmosphere of Doha, Qatar. The main fungal airspora were attributed to Cladosporium, Aspergillus, Fusarium and Alternaria. Among the meteorological parameters, temperature might be the main determinant of the fungal spore incidence and diversity in the atmosphere of Doha. Ganoderma spp. is an allergic fungus which was reported for the first 
time and found to be a major constituent of Doha airspora during February and March. The study also revealed the intra-diurnal pattern of the airborne fungi in the atmosphere of Doha, Qatar, which indicates significant differences in the total colony counts and fungal diversity as a function of time. Both temperature and relative humidity affect the deposition densities of airspora. While other unmonitored air pollutants may have played various roles, here, we demonstrated that increased concentrations of atmospheric $\mathrm{CO}_{2}$ influenced the occurrence of certain fungal taxa. Considering the potentials effects of other air pollutants' influence, it will be of interest to investigate their specific roles in the occurrence, dynamics and diversity of fungal taxa in Doha's atmosphere. The present study is useful for filling the gap of data shortage on the dynamics of fungal taxa in Doha's atmosphere, as well as providing baseline information for allergists, plant pathologists, meteorologists and other scientists. However, two major limitations can be deduced and should be considered for future investigations. The first is the fact that airspora data based on day-to-day spore trapping are more precise and complementary to the gravimetric method used in this study. The second limitation is that a two-month study is not enough to investigate the influence of higher $\mathrm{CO}_{2}$ concentration in the atmosphere on dynamics of airspora, as well as considering the influence of other important air-pollutants is essential.

Author Contributions: Conceptualization, M.H.A.-D.; Data curation, R.K.F.; Investigation, R.K.F., F.A.A.-N. and M.H.A.-D.; Methodology, R.K.F., R.F.A.-T. and F.A.A.-N.; Project administration, M.H.A.-D.; Resources, M.H.A.-D.; Supervision, M.H.A.-D.; Validation, R.F.A.-T. and M.H.A.-D.; Writing-original draft, R.K.F.; Writing-review and editing, F.A.A.-N. and M.H.A.-D. All authors have read and agreed to the published version of the manuscript.

Funding: This research was funded by Qatar University, grant number QUUG-CAS-DHS-13/14-16.

Acknowledgments: We wish to acknowledge and appreciate the financial and technical support from the Office of the Academic Research at Qatar University, under the University grant QUUGCAS-DHS-13/14-16. We would also like to thank Abdulrahman Saleh M Al-Ansari from The Civil Aviation Authority, Metrology Department, Qatar, for the provision of weather data and Abeer Al-Mohannadi for her laboratory technical assistance. The publication of this article was funded by Qatar National Library.

Conflicts of Interest: The authors declare no conflict of interest.

\section{References}

1. Harrison, J.; Pickering, C.; Faragher, E.; Austwick, P.; Little, S.; Lawton, L. An investigation of the relationship between microbial and particulate indoor air pollution and the sick building syndrome. Respir. Med. 1992, 86, 225-235. [CrossRef]

2. Shelton, B.G.; Kirkland, K.H.; Flanders, W.D.; Morris, G.K. Profiles of airborne fungi in buildings and outdoor environments in the United States. Appl. Environ. Microbiol. 2002, 68, 1743-1753. [CrossRef] [PubMed]

3. Reponen, T. Methodologies for Assessing Bioaerosol Exposures. Encycl. Environ. Health 2011, 722-730.

4. D'Amato, G.; Spieksma, F.T.M. Aerobiologic and clinical aspects of mould allergy in Europe. Allergy 1995, 50, 870-877. [CrossRef] [PubMed]

5. Hasnain, S.M.; Al-Frayh, A.; Gad-El-Rab, M.O.; Al-Sedairy, S. Airborne Alternaria spores: Potential allergic sensitizers in Saudi Arabia. Ann. Saudi Med. 2007, 18, 497-501. [CrossRef] [PubMed]

6. Pepeljnjak, S.; Segvić, M. Occurrence of fungi in air and on plants in vegetation of different climatic regions in Croatia. Aerobiologia 2003, 19, 11-19. [CrossRef]

7. Lin, W.-H.; Li, C.-S. Associations of Fungal Aerosols, Air Pollutants, and Meteorological Factors. Aerosol Sci. Technol. 2000, 32, 359-368. [CrossRef]

8. Jothish, P.S.; Nayar, T.S. Airborne fungal spores in a sawmill environment in Palakkad District, Kerala, India. Aerobiologia 2004, 20, 75-81. [CrossRef]

9. Mitakakis, T.Z.; Guest, D. A fungal spore calendar for the atmosphere of Melbourne, Australia, for the year 1993. Aerobiologia 2001, 17, 171-176. [CrossRef]

10. Ibanez, V.; Rojas, G.; Roure, J. Airborne fungi monitoring in Santiago, Chile. Aerobiologia 2001, 17, $137-142$.

11. Stepalska, D.; Wołek, J. Variation in fungal spore concentrations of selected taxa associated. Aerobiologia 2005, 21, 43-52. [CrossRef]

12. Wang, W.; Ma, X.; Ma, Y.; Mao, L.; Wu, F.; Ma, X.; An, L.; Feng, H. Seasonal dynamics of airborne fungi in different caves of the Mogao Grottoes, Dunhuang, China. Int. Biodeterior. Biodegrad. 2010, 64, 461-466. [CrossRef]

13. Barkai-Golan, R.; Glazer, I. Air-borne fungi in eilat and tel-hashomer, Israel. J. Allergy 1962, 33, 342-348. [CrossRef] 
14. Abu-Dieyeh, M.H.; Barham, R. Concentrations and dynamics of fungal spore populations in the air of Zarqa, Jordan, using the volumetric method. Grana 2014, 53, 117-132. [CrossRef]

15. Abu-Dieyeh, M.H.; Barham, R.; Abu-Elteen, K.; Al-Rashidi, R.; Shaheen, I. Seasonal variation of fungal spore populations in the atmosphere of Zarqa area, Jordan. Aerobiologia 2010, 26, 263-276. [CrossRef]

16. Hameed, A.A.; Khoder, M.I.; Yuosra, S.; Osman, A.; Ghanem, S. Diurnal distribution of airborne bacteria and fungi in the atmosphere of Helwan area, Egypt. Sci. Total Environ. 2009, 407, 6217-6222. [CrossRef]

17. Erkara, Í.P.; Asan, A.; Yilmaz, V.; Pehlivan, S.; Okten, S.S.; Yilmaz, V. Airborne Alternaria and Cladosporium species and relationship with meteorological conditions in Eskisehir City, Turkey. Environ. Monit. Assess. 2007, 144, 31-41. [CrossRef]

18. Nourian, A.A.; Badali, H.; Khodaverdi, M.; Hamzehei, H.; Mohseni, S. Airborne mycoflora of Zanjan-Iran. Int. J. Agric. Biol. 2007, 9, 628-630.

19. Abdel-Hafez, S.I.I. Survey of airborne fungus spores at Taif, Saudi Arabia. Mycopathologia 1984, 88, 39-44. [CrossRef]

20. Hasnain, S.M.; Fatima, K.; Al-Frayh, A.; Al-Sedairy, S.T. One-Year pollen and spore calendars of Saudi Arabia Al-Khobar, Abha and Hofuf. Aerobiologia 2005, 21, 241-247. [CrossRef]

21. Halwagy, M.H. Seasonal airspora at three sites in Kuwait 1977-1982. Mycol. Res. 1989, 93, 208-213. [CrossRef]

22. Khan, Z.; Khan, M.; Chandy, R.; Sharma, P. Aspergillus and other moulds in the air of Kuwait. Mycopathologia 1999, 146, 25-32. [CrossRef]

23. Adhikari, A.; Reponen, T.; Grinshpun, S.A.; Martuzevičius, D.; Lemasters, G. Correlation of ambient inhalable bioaerosols with particulate matter and ozone: A two-year study. Environ. Pollut. 2006, 140, 16-28. [CrossRef] [PubMed]

24. Klironomos, J.; Rillig, M.C.; Allen, M.F.; Zak, D.R.; Pregitzer, K.S.; Kubiske, M.E. Increased levels of airborne fungal spores in response to Populus tremuloides grown under elevated atmospheric $\mathrm{CO}_{2}$. Can. J. Bot. 1997, 75, 1670-1673. [CrossRef]

25. Wolf, J.; O’Neill, N.R.; Rogers, C.; Muilenberg, M.L.; Ziska, L.H. Elevated Atmospheric Carbon Dioxide Concentrations Amplify Alternaria alternata Sporulation and Total Antigen Production. Environ. Health Perspect. 2010, 118, 1223-1228. [CrossRef]

26. Al-Subai, A.A. Air-borne fungi at Doha, Qatar. Aerobiologia 2002, 18, 175-183. [CrossRef]

27. Assessing Desert Vegetation Cover Using Remotely Sensed Data: A Case Study from the State of Qatar. Available online: https:/ / pdfs.semanticscholar.org/e28f/a76bf66697727a0db00474b63c3257805db3.pdf?_ga=2.95926108.1958050021.158951 2653-905796193.1587544242 (accessed on 14 May 2020).

28. Richer, R. Conservation in Qatar: Impacts of Increasing Industrialization. SSRN Electron. J. 2009, 2, 27. [CrossRef]

29. Brook, M.C.; Al Shoukri, S.; Amer, K.M.; Böer, B.; Krupp, F. Physical and environmental setting of the Arabian Peninsula and surrounding seas. In Policy Perspectives for Ecosystem and Water Management in the Arabia Peninsula; UNESCO Doha and United Nations University: Hamilton, ON, Canada, 2006; pp. 1-16.

30. Ministry of Development Planning and Statistic. Available online: https://www.mdps.gov.qa/en/pages/default.aspx (accessed on 15 April 2016).

31. Norton, J.; Majid, S.A.; Allan, D.; Al Safran, M.; Böer, B.; Richer, R. An Illustrated Checklist of the Flora of Qatar; Browndown Publications: Gosport, UK, 2009.

32. Booth, C. The Genus Fusarium; Commonwealth Mycological Institute: Kew, UK, 1971.

33. Dunn, M.; Domsch, K.H.; Gams, W.; Anderson, T.-H. Compendium of Soil Fungi. Taxon 1982, 31, 600. [CrossRef]

34. Christensen, M.; Kozakiewicz, Z. Aspergillus Species on Stored Products. Mycopathologia 1990, 82, 407. [CrossRef]

35. Moubasher, A.H. Soil Fungi in Qatar and Other Arab Countries; University of Qatar, Center of Scientific and Applied Research: Doha, Qatar, 1993; p. 566.

36. Pitt, J.I.; Hocking, A.D. Fungi and Food Spoilage; Springer Science and Business Media LLC: Berlin, Germany, 1997.

37. Barnett, H.L.; Hunter, B.B. Illustrated Genera of Imperfect Fungi, 4th ed.; American Phytopathological Society Press: St Paul, MN, USA, 1999.

38. Samson, R.A.; Hoekstra, E.S.; Frisvad, J.C.; Filtenborg, O. Introduction to Food- and Aierborne Fungi; Centraalbureau voor Schimmelcultures: Utrecht, The Netherlands, 2002.

39. Lacey, M.E.; West, J.S. The Air Spora: A Manual for Catching and Identifying Airborne Biological Particles; Springer Science \& Business Media: Berlin, Germany, 2007; pp. 104-112.

40. Sen, B.; Asan, A. Fungal flora in indoor and outdoor air of different residential houses in Tekirdag City (Turkey): Seasonal distribution and relationship with climatic factors. Environ. Monit. Assess. 2008, 151, 209-219. [CrossRef]

41. Quintero, E.; Rivera-Mariani, F.; Rosero, B.B. Analysis of environmental factors and their effects on fungal spores in the atmosphere of a tropical urban area (San Juan, Puerto Rico). Aerobiologia 2009, 26, 113-124. [CrossRef]

42. Burge, H.P.; Solomon, W.R.; Boise, J.R. Comparative merits of eight popular media in aerometric studies of fungi. J. Allergy Clin. Immunol. 1977, 60, 199-203. [CrossRef]

43. Herrero, B.; Fombella-Blanco, M.A.; González, D.F.; Valencia-Barrera, R.M. Aerobiological study of fungal spores from Palencia (Spain). Aerobiologia 1996, 12, 27-35. [CrossRef]

44. Khattab, A.; Levetin, E. Effect of sampling height on the concentration of airborne fungal spores. Ann. Allergy, Asthma Immunol. 2008, 101, 529-534. [CrossRef]

45. Sen, B.; Asan, A. Airborne fungi in vegetable growing areas of Edirne, Turkey. Aerobiologia 2001, 17, 69-75. [CrossRef]

46. Ali, M.; Salama, A.; Ali, T.M. Possible Role of Solar Radiation on the Viability of Some Air Fungi in Egypt. Zbl. Bakt. II Natur. 1976, 131, 529-534. [CrossRef] 
47. Shaheen, I. Aeromycology of Amman area, Jordan. Grana 1992, 31, 223-228. [CrossRef]

48. Asan, A.; Ilhan, S.; Sen, B.; Erkara, I.P.; Filik, C.; Cabuk, A.; Demirel, R.; Ture, M.; Okten, S.S.; Tokur, S. Airborne Fungi and Actinomycetes Concentrations in the Air of Eskisehir City (Turkey). Indoor Built Environ. 2004, 13, 63-74. [CrossRef]

49. Abdel-Hafez, S.I.I.; Shoreit, A.A.M. Mycotoxins producing fungi and mycoflora of air-dust from Taif, Saudi Arabia. Mycopathologia 1985, 92, 65-71. [CrossRef]

50. Christensen, M.; Tuthill, D.E. Aspergillus: An Overview. In Advances in Penicillium and Aspergillus Systematics; Springer Science and Business Media LLC: Berlin, Germany, 1986; pp. 195-209.

51. Smith, S.N. An overview of ecological and habitat aspects in the genus Fusarium with special emphasis on the soil-borne pathogenic forms. Plant. Pathol. Bull. 2007, 16, 97-120.

52. Nelson, P.E.; Dignani, M.C.; Anaissie, E.J. Taxonomy, biology, and clinical aspects of Fusarium species. Clin. Microbiol. Rev. 1994, 7, 479-504. [CrossRef] [PubMed]

53. Fernando, W.G.; Miller, J.D.; Seaman, W.L.; Seifert, K.; Paulitz, T.C. Daily and seasonal dynamics of airborne spores of Fusarium graminearum and other Fusarium species sampled over wheat plots. Can. J. Bot. 2000, 78, 497-505.

54. Gregory, P.H.; Hirst, J.M. The Summer Air-Spora at Rothamsted in 1952. J. Gen. Microbiol. 1957, 17, 135-152. [CrossRef] [PubMed]

55. Grinn-Gofroń, A.; Rapiejko, P. Occurrence of Cladosporium spp. and Alternaria spp. spores in Western, Northern and CentralEastern Poland in 2004-2006 and relation to some meteorological factors. Atmos. Res. 2009, 93, 747-758. [CrossRef]

56. Hasnain, S.M.; Al-Frayh, A.; Khatija, F.; Al-Sedairy, S. AirborneGanodermabasidiospores in a country with desert environment. Grana 2004, 43, 111-115. [CrossRef]

57. Gregory, P.H.; Hirst, J.M.; Gregory, J.M.H.P.H. Possible Role of Basidiospores as Air-borne Allergens. Nature 1952, $170,414$. [CrossRef]

58. Craig, R.L.; Levetin, E. Multi-year study of Ganoderma aerobiology. Aerobiologia 2000, 16, 75-81. [CrossRef]

59. Singh, A.B.; Gupta, S.K.; Pereira, B.M.J.; Prakash, D. Sensitization to Ganoderma lucidum in patients with respiratory allergy in India. Clin. Exp. Allergy 1995, 25, 440-447. [CrossRef]

60. Cabarroi, M.; Maldonado, S.; Del Castillo, L. Hongos del Jardın Botanico Nacional de Cuba. I. Basidiomycota. Rev. del Jard. Bot. de Cuba. 2008, 29, 161-169.

61. Almaguer, M.; Rojas, T.I.; Rodríguez-Rajo, F.J.; Aira, M.J. Airborne basidiospores of Coprinus and Ganoderma in a Caribbean region. Aerobiologia 2013, 30, 197-204. [CrossRef]

62. Grinn-Gofron, A.; Strzelczak, A. Changes in concentration of Alternaria and Cladosporium spores during summer storms. Int. J. Biometeorol. 2012, 57, 759-768. [CrossRef] [PubMed]

63. Sabariego, S.; Bouso, V.; Pérez-Badia, R. Comparative study of airborne Alternaria conidia levels in two cities in Castilla-La Mancha (central Spain), and correlations with weather-related variables. Ann. Agric. Environ. Med. 2012, 19, 227-232. [PubMed]

64. Erkara, Í.P.; Ilhan, S.; Öner, S. Monitoring and assessment of airborne Cladosporium Link and Alternaria Nées spores in Sivrihisar (Eskisehir), Turkey. Environ. Monit. Assess. 2008, 148, 477-484. [CrossRef] [PubMed]

65. Hasnain, S.M.; Akhter, T.; Waqar, M.A. Airborne and allergenic fungal spores of the Karachi environment and their correlation with meteorological factors. J. Environ. Monit. 2012, 14, 1006. [CrossRef]

66. Hameed, A.A.A.; Khoder, M.I.; Emad, A.A. Fertile fungal spores collected on different faced surfaces in the atmosphere of Giza, Egypt. Aerobiologia 2007, 23, 47-57. [CrossRef]

67. Oliveira, M.; Ribeiro, H.; Delgado, L.; Abreu, I. The effects of meteorological factors on airborne fungal spore concentration in two areas differing in urbanisation level. Int. J. Biometeorol. 2008, 53, 61-73. [CrossRef]

68. Segvić, M.; Pepeljnjak, S. A year-round aeromycological study in Zagreb area, Croatia. Ann. Agric. Environ. Med. 2006, 13, 55-64.

69. Grinn-Gofron, A. The occurrence of Ganoderma spores in the air and its relationships with meteorological factors. Acta Agrobot. 2012, 63, 93-97. [CrossRef]

70. McDonald, M.S.; O’Driscoll, B.J. Aerobiological studies based in Galway. A comparison of pollen and spore counts over two seasons of widely differing weather conditions. Clin. Exp. Allergy 1980, 10, 211-215. [CrossRef]

71. Stępalska, D.; Wołek, J. Intradiurnal periodicity of fungal spore concentrations (Alternaria, Botrytis, Cladosporium, Didymella, Ganoderma) in Cracow, Poland. Aerobiologia 2009, 25, 333-340. [CrossRef]

72. Fengxiang, C.; Qingxuang, H.; Zhensheng, C.; Lingyin, M.; Shigang, Y. Factors of influence on microbial pollution in the atmosphere over Beijing area. Aerobiologia 1991, 7, 136-143. [CrossRef]

73. Kurup, V.P.; Shen, H.-D.; Vijay, H. Immunobiology of fungal allergens. Int. Arch. Allergy Immunol. 2002, 129, 181-188. [CrossRef] [PubMed]

74. Ho, H.-M.; Rao, C.; Hsu, H.-H.; Chiu, Y.-H.; Liu, C.-M.; Chao, H.J. Characteristics and determinants of ambient fungal spores in Hualien, Taiwan. Atmos. Environ. 2005, 39, 5839-5850. [CrossRef]

75. Criado, M.R.; Trigo, M.D.M.; Docampo, S.; Melgar, M.; Sánchez, J.G.; Bootello, L.; Cabezudo, B. Analysis of the predicting variables for daily and weekly fluctuations of two airborne fungal spores: Alternaria and Cladosporium. Int. J. Biometeorol. 2011, 56, 983-991. [CrossRef]

76. O'Connor, D.; Sadyś, M.; Skjøth, C.A.; Healy, D.A.; Kennedy, R.; Sodeau, J.R. Atmospheric concentrations of Alternaria, Cladosporium, Ganoderma and Didymella spores monitored in Cork (Ireland) and Worcester (England) during the summer of 2010. Aerobiologia 2014, 30, 397-411. [CrossRef] 
77. Calderón, C.; Lacey, J.; McCartney, H.A.; Rosas, I. Seasonal and Diurnal Variation of Airborne Basidiomycete Spore Concentrations in Mexico City. Grana 1995, 34, 260-268. [CrossRef]

78. Al-Suwaine, A.S.; Hasnain, S.M.; Bahkali, A.H. Viable airborne fungi in Riyadh, Saudi Arabia. Aerobiologia 1999, 15, 121-130. [CrossRef]

79. Chung, H.; Zak, D.R.; Lilleskov, E.A. Fungal community composition and metabolism under elevated $\mathrm{CO}_{2}$ and $\mathrm{O}_{3}$. Oecologia 2005, 147, 143-154. [CrossRef]

80. Hameed, A.A.; Khoder, M.I.; Ibrahim, Y.; Saeed, Y.; Osman, M.; Ghanem, S. Study on some factors affecting survivability of airborne fungi. Sci. Total Environ. 2012, 414, 696-700. [CrossRef]

81. Klamer, M.; Roberts, M.S.; Levine, L.H.; Drake, B.G.; Garland, J.L. Influence of Elevated $\mathrm{CO}_{2}$ on the Fungal Community in a Coastal Scrub Oak Forest Soil Investigated with Terminal-Restriction Fragment Length Polymorphism Analysis. Appl. Environ. Microbiol. 2002, 68, 4370-4376. [CrossRef]

82. Cotty, P.J. Modulation of sporulation of Alternnria tageticn by carbon dioxide. Mycologia 1987, 79, 508-513. [CrossRef]

83. Grinn-Gofroń, A.; Strzelczak, A.; Wolski, T. The relationships between air pollutants, meteorological parameters and concentration of airborne fungal spores. Environ. Pollut. 2011, 159, 602-608. [CrossRef] [PubMed]

84. Lake, J.A.; Wade, R.N. Plant-pathogen interactions and elevated $\mathrm{CO}_{2}$ : Morphological changes in favour of pathogens. J. Exp. Bot. 2009, 60, 3123-3131. [CrossRef] [PubMed]

85. Taj-Aldeen, S.J.; Chandra, P.; Denning, D.W. Burden of fungal infections in Qatar. Mycoses 2015, 58, 51-57. [CrossRef]

86. Taj-Aldeen, S.J.; Hilal, A.A.; Chong-Lopez, A. Allergic Aspergillus flavus rhinosinusitis: A case report from Qatar. Eur. Arch. Oto-Rhino-Laryngol. 2003, 260, 331-335. [CrossRef]

87. Achatz, G.; Oberkofler, H.; Lechenauer, E.; Simon, B.; Unger, A.; Kandler, D.; Ebner, C.; Prillinger, H.; Kraft, D.; Breitenbach, M. Molecular cloning of major and minor allergens of Alternaria alternata and Cladosporium herbarum. Mol. Immunol. 1995, 32, 213-227. [CrossRef]

88. Hedayati, M.T.; Pasqualotto, A.C.; Warn, P.A.; Bowyer, P.; Denning, D.W. Aspergillus flavus: Human pathogen, allergen and mycotoxin producer. Microbiology 2007, 153, 1677-1692. [CrossRef] 